\title{
Dynamics of Hydrology and Anaerobic Hydrocarbon Degrader Communities in A Tar-Oil Contaminated Aquifer
}

\author{
Giovanni Pilloni 1,+ ${ }^{\mathbb{D}}$, Anne Bayer ${ }^{1, \ddagger}$, Bettina Ruth-Anneser ${ }^{1, \S}$, Lucas Fillinger ${ }^{1}$, \\ Marion Engel ${ }^{2}$, Christian Griebler ${ }^{1, \|}$ and Tillmann Lueders $1, *, \mathbb{I}(\mathbb{D}$ \\ 1 Institute of Groundwater Ecology, Helmholtz Zentrum München-German Research Center for \\ Environmental Health, 85764 Neuherberg, Germany; giovanni.pilloni@exxonmobil.com (G.P.); \\ anne.bayer@lfu.bayern.de (A.B.); bettina.ruth-anneser@fh-rosenheim.de (B.R.-A.); \\ lucas.fillinger@helmholtz-muenchen.de (L.F.); christian.griebler@univie.ac.at (C.G.) \\ 2 Research Unit Comparative Microbiome Analysis and Research Unit Scientific Computing, \\ Helmholtz Zentrum München-German Research Center for Environmental Health, \\ 85764 Neuherberg, Germany; marion.engel@helmholtz-muenchen.de \\ * Correspondence: tillmann.lueders@uni-bayreuth.de \\ + Present address: ExxonMobil Research and Engineering, Annandale, NJ 08801, USA. \\ $\ddagger$ Present address: Bavarian Environment Agency, 82407 Wielenbach, Germany. \\ $\S$ Present address: Technische Hochschule Rosenheim, 83024 Rosenheim, Germany. \\ || Present address: University of Vienna, Center of Functional Ecology, \\ Department of Limnology \& Bio-Oceanography, 1090 Vienna, Austria. \\ II Present address: Department of Ecological Microbiology, University of Bayreuth, 95440 Bayreuth, Germany.
}

Received: 21 December 2018; Accepted: 6 February 2019; Published: 9 February 2019

check for updates

\begin{abstract}
Aquifers are typically perceived as rather stable habitats, characterized by low biogeochemical and microbial community dynamics. Upon contamination, aquifers shift to a perturbed ecological status, in which specialized populations of contaminant degraders establish and mediate aquifer restoration. However, the ecological controls of such degrader populations, and possible feedbacks between hydraulic and microbial habitat components, remain poorly understood. Here, we provide evidence of such couplings, via 4 years of annual sampling of groundwater and sediments across a high-resolution depth-transect of a hydrocarbon plume. Specialized anaerobic degrader populations are known to be established at the reactive fringes of the plume. Here, we show that fluctuations of the groundwater table were paralleled by pronounced dynamics of biogeochemical processes, pollutant degradation, and plume microbiota. Importantly, a switching in maximal relative abundance between dominant degrader populations within the Desulfobulbaceae and Desulfosporosinus spp. was observed after hydraulic dynamics. Thus, functional redundancy amongst anaerobic hydrocarbon degraders could have been relevant in sustaining biodegradation processes after hydraulic fluctuations. These findings contribute to an improved ecological perspective of contaminant plumes as a dynamic microbial habitat, with implications for both monitoring and remediation strategies in situ.
\end{abstract}

Keywords: BTEX; anaerobic toluene degradation; benzylsuccinate synthase; microbial community dynamics; next-generation sequencing

\section{Introduction}

Over $97 \%$ of global non-glacial freshwater resources are retained in groundwater [1], which constitutes the main source of drinking water in many areas of the world. Despite this key relevance for our society, aquifers are still poorly understood as ecosystems, especially regarding the ecology of 
their primary populace, the microbes [2]. In contrast to many other aquatic ecosystems, aquifers have been classically perceived as mostly steady-state habitats, not subject to pronounced diurnal or seasonal dynamics, and characterized by a rather stable hydrology, redox, temperature, as well as availability of energy and nutrients [3,4]. Even after contamination, for example, by petroleum hydrocarbons, steady-state contaminant plumes and respective anoxic redox compartments are understood to establish and to be attenuated over time scales of decades to centuries [5]. While contamination clearly represents a fundamental perturbation of aquifer microbes and ecosystem status [6-10], a better understanding of the ecology of contaminant plumes is needed to improve site-specific prediction and restoration strategies [11].

At a tar-oil contaminated aquifer in Düsseldorf-Flingern in Germany, we have previously shown that a locally enriched population of specialized anaerobic degraders had established at the sulfidogenic lower fringe of a toluene plume, indicative of a "hot-spot" of biodegradation in situ [12-15]. This was consistent with the hypothesis that degraders are primarily controlled by the limited dispersive mixing of electron donors and acceptors in porous media, thus largely restricting their activities to the reactive fringes of contaminant plumes [16]. To further elaborate the importance of such plume fringes for overall biodegradation, it is relevant to understand them as microbial habitats, and to elucidate possible ecological factors limiting the establishment and activity of degrader populations. Especially, possible feedbacks between abiotic habitat dynamics, such as fluctuating groundwater tables and degrader populations, have been rarely addressed to date.

It has been previously demonstrated that fluctuating groundwater levels can drive dynamics in contaminant distribution and related biogeochemical processes [17-19]. Moreover, Haack et al. observed general rearrangements of aquifer bacterial communities and a loss of diversity in distinct zones of a hydrocarbon plume after hydraulic dynamics [20]. However, the potentially complex interplay between hydraulic and microbial parameters in groundwater is still considered as one of the key unknowns in aquifer restoration today [21]. Most of the aforementioned studies have sampled microbes from groundwater and not from sediments [17-20], where spatially explicit depth-resolved interpretation is more straightforward [11,22]. In the present study, we hypothesize that anaerobic degrader communities established at the reactive fringe of the previously characterized toluene plume could respond to hydraulic habitat fluctuations by community rearrangements. We follow up on this via four years of repetitive depth-resolved groundwater and sediment sampling at the tar-oil contaminated Flingern aquifer, as well as comprehensive hydrogeochemical, isotopic, and microbial community analyses.

\section{Materials and Methods}

\subsection{Site Sampling and Hydrochemical Analyses}

Sediment and groundwater were sampled at a well-studied tar-oil contaminated aquifer in Düsseldorf-Flingern (Germany) [12-15]. The aquifer is dominated by medium and coarse sands, with thin interspersed gravel layers at depths below $10 \mathrm{~m}$. The hydraulic conductivity of the aquifer is $\sim 10^{-3} \mathrm{~m} \cdot \mathrm{s}^{-1}$, with a mean groundwater flow velocity at $\sim 1 \mathrm{~m} \cdot \mathrm{d}^{-1}$ [23]. The intrinsic hydrocarbon plume is dominated by toluene $(\sim 60-80 \%$ of total petroleum hydrocarbons) and sulfidogenic degradation [12-15]. Water samples from a high-resolution multi-level well (HR-MLW) were collected between $~ 5.5$ and 8.5 m depth in February 2006 [13], February 2007, September 2008, and June 2009. For relevant plume compartments, depth-resolved monitoring was conducted with a depth resolution as little as 5-10 cm. In part, data from a previous sampling in September 2005 [12,24] are also included in the present study. Hydrogeochemical parameters were analyzed from water samples as previously described [14,24]. In addition, toluene $\delta^{13} \mathrm{C} /{ }^{12} \mathrm{C}$ isotope ratios were analyzed from duplicate $\mathrm{NaOH}$-preserved samples with gas chromatography-combustion-isotope ratio mass spectrometry (GC-C-IRMS, Thermo Fisher, Bremen, Germany) via purge and trap analysis [25] and gas chromatographic separation adapted to benzene, toluene, ethylbenzene, and xylenes (BTEX). 
A DB624-column (Supelco, Bellefonte, PA, USA) and an optimized temperature program (3.07 $\mathrm{min}$ at $60{ }^{\circ} \mathrm{C}, 8.1^{\circ} \mathrm{C} / \mathrm{min}$ to $129^{\circ} \mathrm{C}, 1^{\circ} \mathrm{C} / \mathrm{min}$ to $134{ }^{\circ} \mathrm{C}, 20^{\circ} \mathrm{C} / \mathrm{min}$ to $180^{\circ} \mathrm{C}, 50{ }^{\circ} \mathrm{C} / \mathrm{min}$ to $230{ }^{\circ} \mathrm{C}$, hold $5 \mathrm{~min}$ ) were used. The standard deviations for duplicate toluene $\delta^{13} \mathrm{C} /{ }^{12} \mathrm{C}$ isotope measurements were much lower than the instrumental uncertainty and were therefore set to $0.5 \%$ as recommended [26].

At matching time points in 2006, 2007, and 2009, water samples were also taken by the site owner (SWD, Stadtwerke Düsseldorf, Germany) from the surrounding network of conventional monitoring wells to assess the horizontal extent of the plume. For these samples, concentrations of BTEX compounds were quantified following standardized methods (DIN 38407-F9:1991-05) by a certified analytical laboratory of the SWD. Plume extent was interpolated by Kriging by the SWD for samples taken in 2006 and 2007, as well as for 2009 by BFM-Umwelt (Munich, Germany) using Surfer 9.0 (Golden Software Inc., Golden, CO, USA).

For sediment sampling, intact sediment liners were taken as direct-push cores within distances of 0.5 to $1 \mathrm{~m}$ next to the HR-MLW in February 2006, September 2008, and June 2009. Sediment liners were retrieved with a direct-push drilling rig (Geoprobe, Salina, KS, USA) and shock-frozen on dry ice directly after retrieval. Per drilling, eight sediment depths representing all major plume compartments over a depth range between 5.5 and $8.5 \mathrm{~m}$ below ground were sub-sampled as micro-cores from the sediment liners with cut sterile syringes, then handled and analyzed as described [12,13].

\subsection{Molecular Analyses}

DNA templates were extracted from triplicate frozen sediment sub-samples of each depth within 6-12 months after sampling. DNA was extracted from sediment aliquots suspended in $650 \mathrm{~mL}$ PTN buffer (120 mM Na $2 \mathrm{HPO}_{4}, 125 \mathrm{mM}$ Tris, $0.25 \mathrm{mM} \mathrm{NaCl}\left(\mathrm{pH}\right.$ 8)) and incubated at $37{ }^{\circ} \mathrm{C}$ for $15 \mathrm{~min}$ with $40 \mathrm{~mL}$ lysozyme $\left(50 \mathrm{mg} \cdot \mathrm{mL}^{-1}\right)$ and $10 \mathrm{~mL}$ proteinase $\mathrm{K}\left(10 \mathrm{mg} \cdot \mathrm{mL}^{-1}\right)$. After adding $150 \mathrm{~mL}$ $20 \%(w t / v)$ sodium dodecyl sulfate, the incubation was prolonged for $15 \mathrm{~min}$ at $65^{\circ} \mathrm{C}$ in a shaker at $500 \mathrm{rpm}$. The slurries were then bead beaten $\left(45 \mathrm{~s}\right.$ at $6.5 \mathrm{~ms}^{-1}$ ) in a FastPrep-24 (MP Biomedicals, Solon, $\mathrm{OH}$, USA) with $0.2 \mathrm{~mL}$ of zirconia-silica beads (1:1 mix of 0.1-mm and 0.7-mm in diameter; Roth, Karlsruhe, Germany) and $100 \mathrm{~mL}$ of phenol-chloroform-isoamyl alcohol (25:24:1) in 2-mL screw-cap vials. Subsequently, the nucleic acids were sequentially purified by extraction with 1 volume of phenol-chloroform-isoamyl alcohol (25:24:1) and 1 volume of chloroform-isoamyl alcohol (24:1). Purified nucleic acids were then precipitated with 2 volumes of $30 \%$ polyethylene glycol by incubation at $4{ }^{\circ} \mathrm{C}$ for at least $2 \mathrm{~h}$ and subsequently centrifuged at $20,000 \times g$ and $20{ }^{\circ} \mathrm{C}$ for $30 \mathrm{~min}$. All chemicals used in the DNA extraction were from Sigma-Aldrich (St. Louis, MO, USA) unless otherwise specified. For each biological sample, two parallel sediment extractions were pooled in $60 \mathrm{~mL}$ of elution buffer and stored at $-20^{\circ} \mathrm{C}$ until further analysis. Extracted nucleic acids were first subjected to terminal restriction fragment length polymorphism (T-RFLP) fingerprinting of bacterial 16S rRNA genes, as previously described [27]. Amplicons for T-RFLP were generated using the $5^{\prime}$-FAM-labelled primer Ba27f (5'-aga gtt tga tcm tgg ctc ag-3') and the unlabeled primer 907r ( $5^{\prime}$-ccg tca att cct ttg agt tt- $\left.3^{\prime}\right)$ in a Mastercycler ep gradient (Eppendorf, Hamburg, Germany) with the following cycling conditions: initial denaturation $\left(94^{\circ} \mathrm{C}, 5 \mathrm{~min}\right)$, followed by 24 or 28 cycles of denaturation $\left(94{ }^{\circ} \mathrm{C}, 30 \mathrm{~s}\right)$, annealing $\left(52{ }^{\circ} \mathrm{C}, 30 \mathrm{~s}\right)$, and elongation $\left(70{ }^{\circ} \mathrm{C}, 60 \mathrm{~s}\right)$. Each $50 \mathrm{~mL}$ PCR reaction contained $1 \times$ PCR buffer, $1.5 \mathrm{mM} \mathrm{MgCl}_{2}, 0.1 \mathrm{mM}$ dNTPs, $1.25 \mathrm{U}$ recombinant Taq polymerase (all from Fermentas, St. Leon-Rot, Germany), $0.2 \mathrm{mg} \mathrm{mL}^{-1}$ bovine serum albumin (BSA) (Roche, Penzberg, Germany), $0.5 \mathrm{mM}$ of each primer (Biomers, Ulm, Germany), and $1 \mu \mathrm{L}$ of template DNA. Amplicons were restricted using MspI and separated by capillary electrophoresis.

Quantitative PCR (qPCR) of anaerobic toluene degradation genes (benzylsuccinate synthase $\alpha$-subunit, bss A) and total bacterial 16S rRNA genes was also done as previously described [12]. The utilized bss $A$ detection assay was specific for the Desulfobulbaceae-related "F1-cluster" bss $A$ previously shown to dominate at the site [12]. BssA qPCR was performed with a TaqMan universal master mix kit (Applied Biosystems) with the primers bssApd2f ( $5^{\prime}$-cct atg cga cga gta agg tt- $\left.3^{\prime}\right)$ and bssApd2r (5'-tga tag caa cca tgg aat tg- $\left.3^{\prime}\right)$ used in combination with the probe bssApd2h $\left(5^{\prime}-\mathrm{tcc} \operatorname{tgc}\right.$ 
aaa tgc ctt ttg tct caa-3'). A thermal cycle of initial denaturation at $95^{\circ} \mathrm{C}$ for $10 \mathrm{~min}$ was followed by 50 cycles of denaturation at $95^{\circ} \mathrm{C}$ for $15 \mathrm{~s}$, annealing at $55^{\circ} \mathrm{C}$ for $20 \mathrm{~s}$, and final elongation at $72{ }^{\circ} \mathrm{C}$ for $30 \mathrm{~s}$. Total bacterial 16S rRNA genes were quantified using a previously described Sybr green PCR approach using the primers Ba519f ( $5^{\prime}$-cag cmg ccg cgg taa nwc- $\left.3^{\prime}\right)$ and Ba907r. We used standard Taq polymerase (Fermentas) assays in the presence of $0.1 \times$ Sybr green (FMC Bio Products, Philadelphia, PA, USA) and $2 \mu \mathrm{l}$ DNA template. Initial denaturation $\left(94^{\circ} \mathrm{C}, 3 \mathrm{~min}\right)$ was followed by 50 cycles of denaturation $\left(94{ }^{\circ} \mathrm{C}, 15 \mathrm{~s}\right)$, annealing $\left(52{ }^{\circ} \mathrm{C}, 15 \mathrm{~s}\right)$, and elongation $\left(70{ }^{\circ} \mathrm{C}, 30 \mathrm{~s}\right)$. Both qPCRs were performed on a MX3000P qPCR cycler (Stratagene, La Jolla, CA, USA). For each sediment depth, the three biological DNA extracts were quantified in three different dilutions (undiluted, 1:5, and 1:10) to account for the possibility of PCR inhibition.

After initial T-RFLP and qPCR screening, 16S rRNA gene amplicon pools from five depths between 6.4 and $8.4 \mathrm{~m}$ below ground were chosen for each year and subjected to amplicon pyrosequencing on a FLX Genome Sequencer (Roche-454 Life Sciences, Branford, CT, USA). Sequencing was done from deep-frozen DNA extracts $\left(-80^{\circ} \mathrm{C}\right)$ using Titanium chemistry (Roche) as previously described [28,29]. Amplicons for multiplexing were prepared with the primers Ba27f and Ba519r ( $5^{\prime}$-tat tac cgc ggc kgc $\operatorname{tg}-3^{\prime}$ ) extended as amplicon fusion primers with respective primer A or B adapters, key sequences, and multiplex identifiers (MIDs). Sequence data denoising, quality trimming, and chimera checking was performed using mothur v.1.34.3 [30] as previously described [29]. Subsequently, sequences were classified using the SILVAngs data analysis platform [31]. Default settings were used for quality control, de-replication, OTU clustering, and classification at a 97\% sequence identity level. Taxonomic assignments were based on the SILVA database release 123 (24 July 2014).

Contigs were generated for dominant amplicons to allow for phylogenetic reconstruction and T-RF prediction as previously described $[27,28]$. Briefly, contigs were assembled from matching forward and reverse reads with the SEQMAN II software (DNAStar) using assembly thresholds of at least $98 \%$ sequence similarity over a 50-bp match window. Contigs without at least one forward and one reverse read were not considered for further analysis. All pyrosequencing reads generated in this study have been deposited in NCBI's Sequence Read Archive and are accessible as SRA study SRP004457. Selected assembled amplicon contigs of dominating populations have been deposited with GenBank under the accession numbers HQ596373 to HQ596401.

\subsection{Data Handling and Statistics}

Shannon diversity $\left(H^{\prime}\right)$ and functional organization $\left(F_{0}\right)$ of communities were inferred for OTUs obtained from rarefied sequencing libraries ( $n=1200$ processed reads for each). Fo is an evenness indicator based on Pareto-Lorenz curves [32]. As in $H^{\prime}$, community richness and relative abundances of individual taxa are incorporated. However, rare taxa are less important, as only the cumulative relative abundance of the top $20 \%$ of the most abundant OTUs is considered. Fo would be 0.2 at perfect evenness; the higher the Fo, the more organized, less diverse, and less even the respective community.

Canonical correspondence analysis (CCA) was used to examine the assembly of taxonomic groups along gradients of environmental variables [33] measured across the plume. CCA was performed in $\mathrm{R}$ (version 3.3.2) using the vegan package [34]. The significance of CCA axes and explanatory variables was assessed by permutation tests with 1000 permutations using the 'anova.cca' function. Variables were selected by backward selection starting with a full model containing toluene concentration, sulfide concentration, depth below surface, bss A gene copy numbers, and groundwater level. Only significant variables $(p<0.05)$ were retained in the final model. Principal component analysis (PCA) was done using the 'prcomp' function implemented in $\mathrm{R}$ to analyze changes in the relative abundances of taxonomic groups over the years for individual plume zones (upper and lower plume fringe, deeper zone). 


\section{Results}

\subsection{Hydraulic Dynamics and Plume Fluctuation}

Considerable dynamics of the groundwater table (GWT) were observed at the site during four years of sampling (Figure 1). A drop of the GWT of almost $40 \mathrm{~cm}$ between July 2006 and January 2007 was followed by a constant rise of $\sim 60 \mathrm{~cm}$ until March 2009. After this, an equivalent but more rapid decline of the water table was observed until winter 2009.

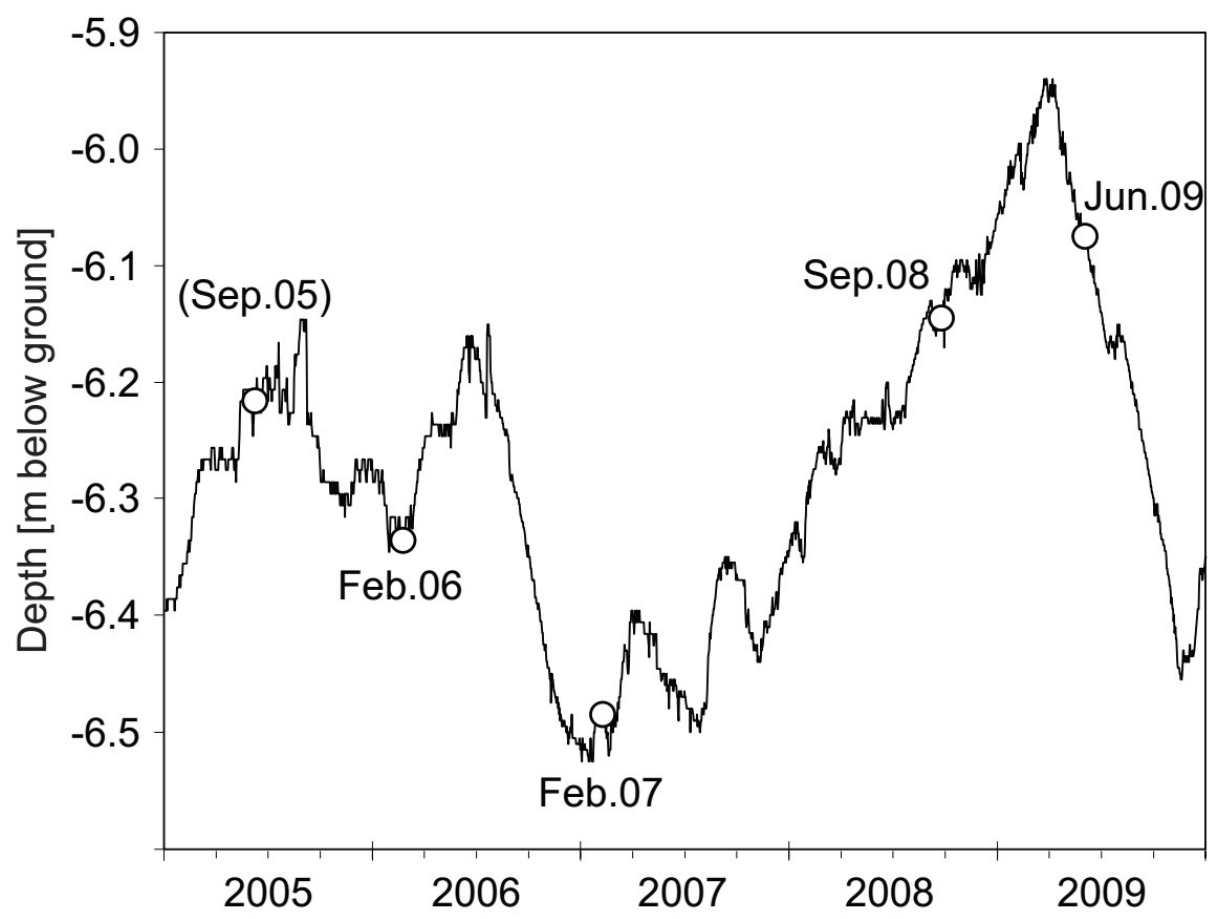

Figure 1. Fluctuation of the groundwater table over the period of investigation. Measurements were performed using water table logging in the conventional monitoring wells 19179 and 19223 (Figure S1) adjacent to the high-resolution multi-level well (HR-MLW) used for high-resolution water and sediment sampling. Circles indicate the four time points of sediment and groundwater sampling, and one time point of groundwater sampling only (February 2007). Field data from September 2005 have been previously reported [12].

Between the samplings in February 2006 and February 2007, the drop of the water table was reflected in a downshift of the toluene plume core from $\sim 6.6$ to $6.8 \mathrm{~m}$ depth, while maximal concentrations remained at $\sim 40 \mathrm{mg} \cdot \mathrm{L}^{-1}$ (Figure 2a). The reactive lower fringe of the plume remained localized at $\sim 7.1 \mathrm{~m}$ depth (similar to the lower fringe reported by Winderl et al. [12] for 2005) and reactive, as suggested by an increase of $\delta^{13} \mathrm{C}$ ratios of toluene from approximately $-24 \%$ to $-21 \%$ o in this zone (Figure 2b). Maximal sulfide concentrations at the lower fringe, however, decreased from $\sim 10$ to $\sim 2 \mathrm{mg} \cdot \mathrm{L}^{-1}$ over the same time (Figure 2c). In September 2008, after the rise of the GWT, a corresponding upshift of the plume core was paralleled by a doubling of maximum toluene concentrations to $\sim 100 \mathrm{mg} \cdot \mathrm{L}^{-1}$, now at $\sim 6.5 \mathrm{~m}$ depth. A peak of sulfide concentrations of $\sim 10 \mathrm{mg} \cdot \mathrm{L}^{-1}$, now at $6.9 \mathrm{~m}$ depth, indicated a stimulation and upshift of sulfidogenesis. However, a loss of notable $\delta^{13} \mathrm{C}$ fractionation was observed for toluene at the plume fringes in 2008 (Figure 2b). Instead, overall $\delta^{13} \mathrm{C}$ ratios of toluene appeared to level out at slightly increased ratios $(-23 \%$ to $-22 \%$ ) over the plume. In June 2009, maximal toluene concentrations in the plume core dropped markedly, to $\sim 18 \mathrm{mg} \cdot \mathrm{L}^{-1}$ now at $6.6 \mathrm{~m}$ depth (Figure $2 \mathrm{a}$ ). Maximal sulfide concentrations of $\sim 6$ to $\sim 7 \mathrm{mg} \cdot \mathrm{L}^{-1}$ were observed at both the upper $(6.4 \mathrm{~m}$ depth) and lower $(6.9 \mathrm{~m})$ plume fringes, connected to a partial re-establishment of toluene $\delta^{13} \mathrm{C}$ isotope fractionation, however, mostly at the upper plume fringe ( $-20.5 \%$ at $6.4 \mathrm{~m}$ depth). 
Toluene $\left[\mathrm{mg} \mathrm{I}^{-1}\right]$

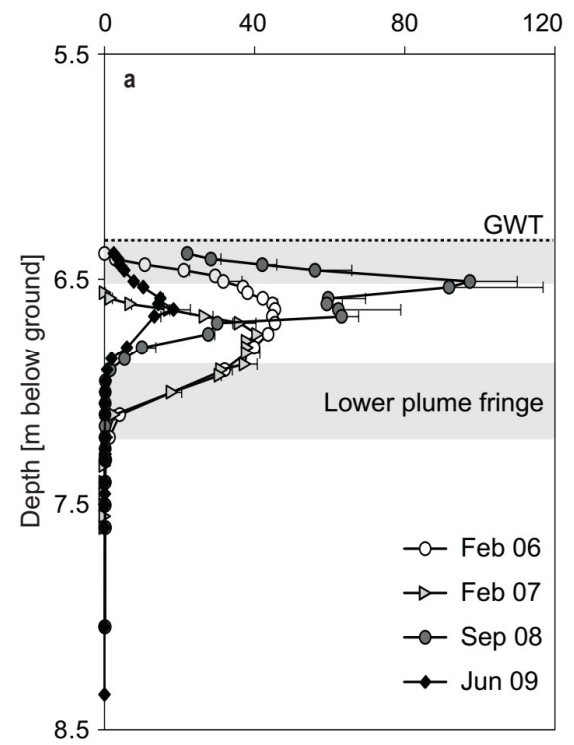

$\delta^{13} \mathrm{C} /{ }^{12} \mathrm{C}$-toluene [\% vs. VPDB]

$\begin{array}{lll}-25 & -22 & -19\end{array}$

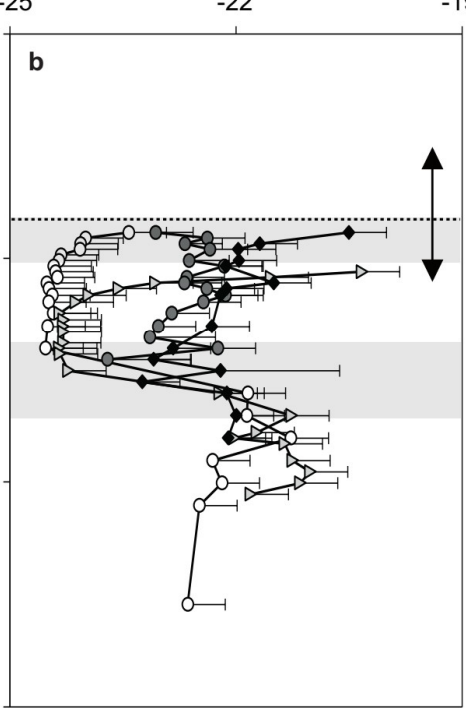

Sulfide $\left[\mathrm{mg}^{-1}\right]$

6

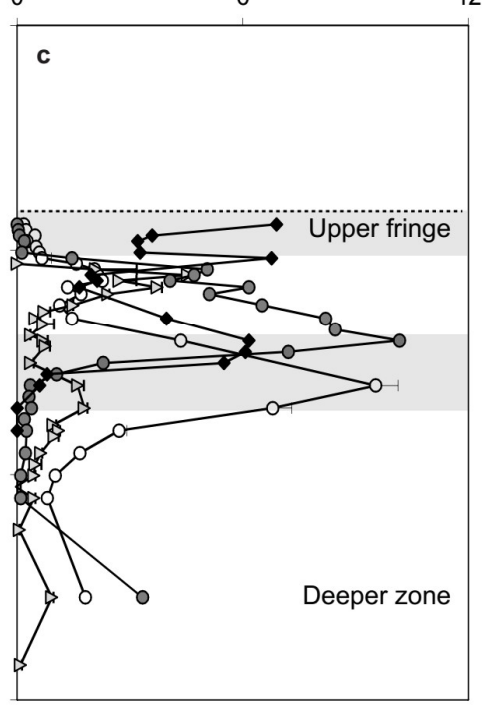

Figure 2. Depth profiles of toluene concentration, biodegradation, and sulfide in the Flingern aquifer over four successive sampling time points. (a) Toluene concentrations plus standard deviation (positive only); (b) toluene stable isotope ratios plus standard deviation (positive only); (c) sulfide concentrations plus standard deviation (positive only) from duplicate groundwater samples per time point and depth. The extent of groundwater table (GWT) fluctuations and shifts of the plume boundaries during the study period are indicated as a vertical arrow (at GWT). The localization of the upper and lower plume fringes is highlighted in grey, but averaged over the entire study period.

The horizontal extent and localization of the Flingern BTEX plume, as monitored by the site owner, remained stable over the whole period (Figure S1). The HR-MLW was always centrally placed in the transect of the plume over the years, and pronounced lateral fluctuations of the plume or groundwater flow were not observed. At the same time, the concentration of other, less abundant contaminants also detectable at the site (e.g., benzene, naphthalene) remained constant or even increased in concentration in the plume core between 2008 and 2009 (Figure S2), thus not reflecting the marked drop in toluene concentrations over the same time.

\subsection{Dynamics of Plume Microbiota}

Sediment bacterial 16S rRNA gene counts (maximally $\sim 2 \times 10^{8}$ in the plume core in 2005 and 2006) dropped by an order of magnitude throughout the plume core in 2008 , but were still on a level comparable to the qPCR results of $2005\left(\sim 2 \times 10^{7}\right)$ at the lower fringe (Figure 3a). In 2009, the depth profile of bacterial 16S rRNA gene counts was again comparable to that before 2008. Anaerobic toluene degraders were quantified via a qPCR assay established for the Desulfobulbaceae-related benzylsuccinate synthase $\alpha$-subunit (bss $A$ ) genes of previously dominating degraders at the site [12,27]. Compared to the maximum catabolic gene counts of $>10^{7}$ per gram of sediment observed for the lower plume fringe in 2005 [12] and also in 2006 (Figure 3b), a decrease of this gene pool by over an order of magnitude was observed in 2008. Still, the ratio of Desulfobulbaceae-related $b s s A$ genes to total bacterial 16S rRNA gene counts continued to be highest at the lower plume fringe (Figure 3c). However, gene enrichment was clearly higher ( $\sim .5$ to 0.8$)$ before than after ( $\sim 0.1$ to 0.2$)$ the hydraulic dynamics between 2007 and 2008. 

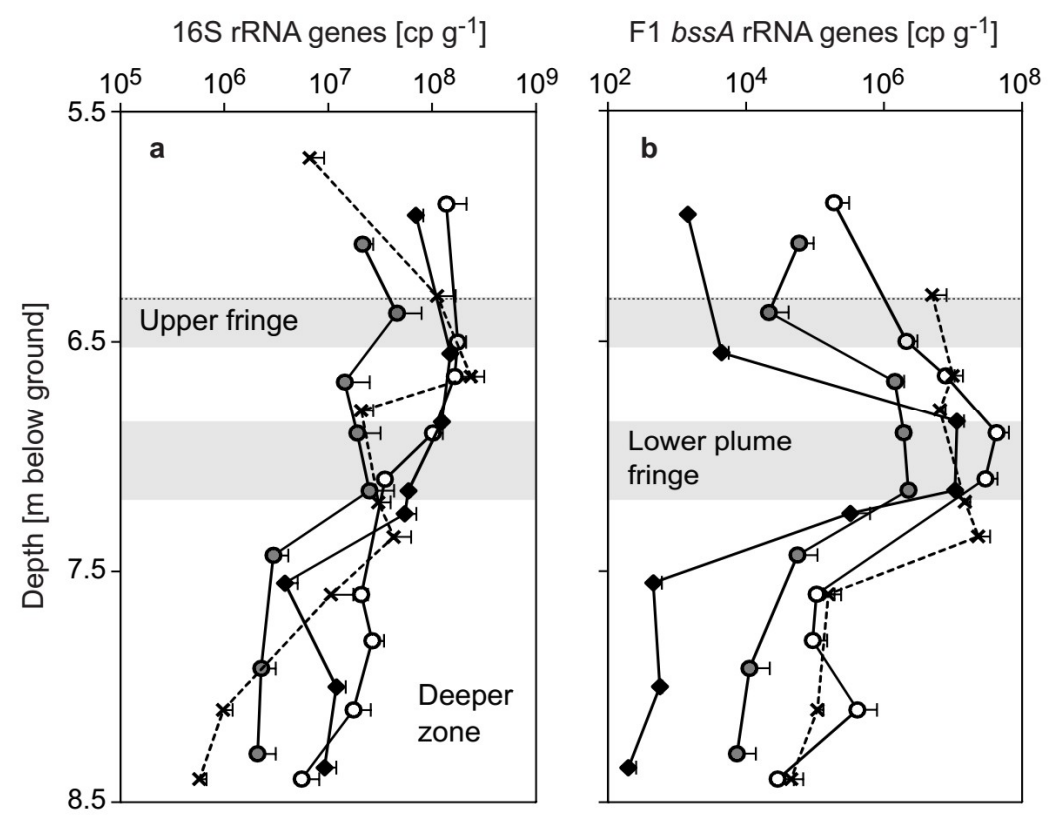

bssA / 16S gene ratio

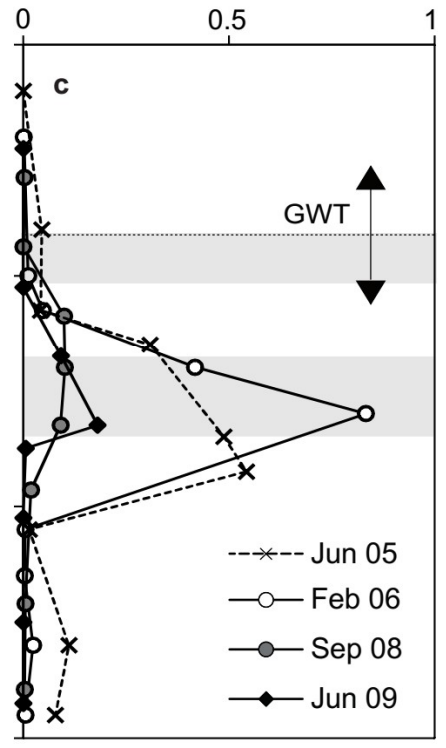

Figure 3. Depth profiles of sedimentary bacterial rRNA genes and anaerobic toluene degradation genes at the Flingern aquifer during the study. (a) Total bacterial 16S rRNA genes and (b), 'F1-cluster' $b s s A$ genes $[12,35]$ as quantified via qPCR of triplicate sediment DNA extracts. Shown are average gene counts $\mathrm{g}^{-1}$ sediment plus standard error (positive only). (c) Relative $b s s A$ gene abundance within total gene counts. Data from June 2005 were already reported previously [12]. Further details are as in Figure 2.

High-throughput sequencing of $16 \mathrm{~S}$ rRNA gene amplicons of sedimentary bacteria was performed for more detailed structural insights into the Flingern plume microbiota. For the present study, amplicon libraries from five depths over the plume transect taken in 2006, 2008, and 2009 were sequenced. The libraries contained an average of $\sim 2700$ reads per sample at a threshold of $>250 \mathrm{bp}$ quality-trimmed read length.

Bacteria at the upper plume fringe were dominated by members of the Alpha-, Beta-, and Gammaproteobacteria, as well as by Acidobacteria (Figure 4). Between the three sampling time points, abundance shifts were mostly observed for reads related to Thiobacillus spp., which was abundant (up to $\sim 10 \%$ of total reads) in 2006 and 2009, but almost not detectable after the rise of the GWT in 2008 . In contrast, diverse unclassified Gammaprotobacteria appeared especially abundant in $2008(\sim 33 \%)$. An increase of sequences within the Acidobacteria ( 20\%), many related to Geothrix spp. ( 7\%), was observed at the upper fringe in 2009.

Bacteria at the lower plume fringe were always dominated by reads within the Deltaproteobacteria, Betaproteobacteria, and Clostridia (Figure 4). Within the Deltaproteobacteria, sequencing reads related to Geobacter spp. were stable in abundance ( 18-20\%) over the years, but almost absent in other depths. In contrast, a high abundance of reads within the Desulfobulbaceae ( 30\% and $42 \%$ in 2006 and 2008, respectively) decreased to only $\sim 9 \%$ in 2009. Vice versa, reads related to Desulfosporosinus spp. within the Peptococcaceae (Clostridia) constantly increased in abundance, from only $~ 8 \%$ in 2006 to $\sim 26 \%$ in 2009 . The diversity of rarefied amplicon pools was always lowest at the lower plume fringe (Figure S3a), consistent with a peaking 'functional organization' ( $F o$ ) of these communities (Figure S3b).

Finally, amplicon pools from the deeper zone revealed distinct, but much more stable communities over the years. They were also dominated by Deltaproteobacteria and Clostridia, but also by Chloroflexi $(\sim 11 \%)$. The Deltaproteobacteria from the deeper zone, in contrast to those recovered at the lower plume fringe, were mostly affiliated to the Desulfobacteraceae (up to $23 \%$ ), as well as to other unclassified Deltaproteobacteria. High ratios (up to $38 \%$ ) of bacterial reads unclassified at the phylum level were also found at these depths. 


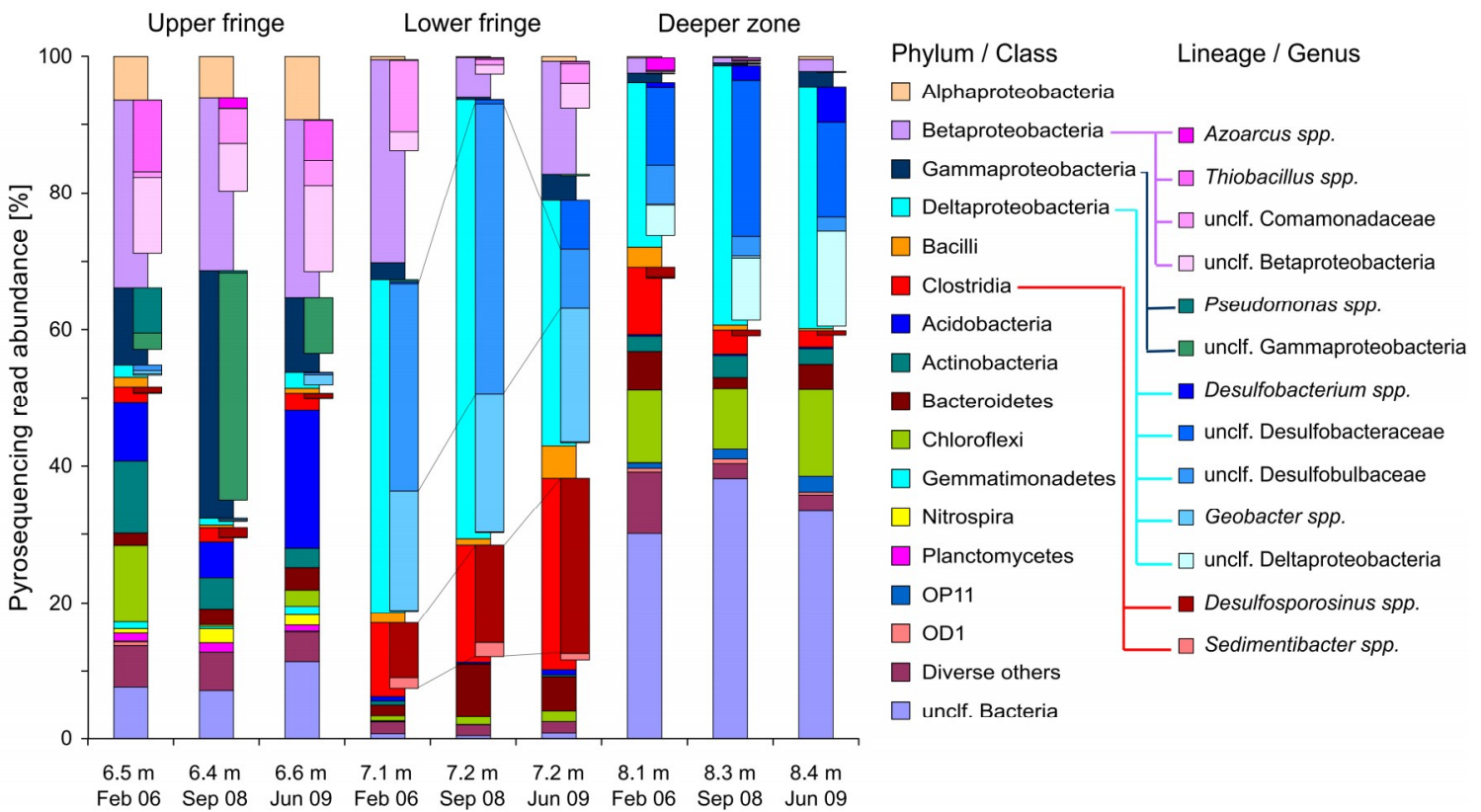

Figure 4. Temporal bacterial community dynamics in compartments of the Flingern hydrocarbon plume as revealed by amplicon pyrosequencing of $16 \mathrm{~S}$ rRNA gene fragments. Total communities are resolved to phylum/class-level, while selected dominating and dynamic lineages are highlighted at the genus-level.

We have previously demonstrated a high reproducibility and semi-quantitative accuracy of relative OTU abundances across biologically replicated sequencing libraries for a series of triplicate DNA extracts from sediments taken from the plume core $(\sim 6.8 \mathrm{~m}$ depth $)$ in the same sampling campaign [28]. Still, as the community shifts observed for the different time points and depths in the present study resulted from non-replicated sequencing libraries, we aimed to confirm the most important population dynamics via biologically replicated T-RFLP fingerprinting. For this, amplicon contigs of dominating degrader populations at the lower plume fringe were assembled and corresponding T-RFs were predicted (Figure S4). The results were consistent with previous T-RF assignments for populations at the site $[12,13,27,28,36]$. As expected, degrader populations within the Desulfobulbaceae, the Geobacteraceae, and the Peptococcaceae were affiliated to the 159, the 129, as well as the 138 and $228 \mathrm{bp}$ T-RFs, respectively (Figure S5). While the abundance profile of the 129 bp fragment (Geobacter spp.) was rather stable over time, maximal abundance of the $159 \mathrm{bp}$ T-RF (Desulfobulbaceae) was consistently reduced at the lower plume fringe in June 2009 (from $~ 45 \%$ to $\sim 15 \%$ abundance at $\sim 7.1 \mathrm{~m}$ depth). In contrast, the signal of the combined 138 and $228 \mathrm{bp} \mathrm{T-RFs}$ (Desulfosporosinus spp.) more than doubled (from $\sim 10 \%$ to $\sim 30 \%$ at $7.1 \mathrm{~m}$ depth) in the same year (Figure S4).

\subsection{Multivariate Statistics of Degrader Dynamics}

Multivariate statistics substantiated the marked distinctions between sequencing OTUs detected in samples from the different depth zones respectively, as well as their association to signifying environmental variables (Figure 5a). At the upper fringe, especially the abundance of Alphaproteobacteria, Pseudomonas, and Thiobacillus spp. correlated with high toluene concentrations and shallow depth. In contrast, Desulfosporosinus and Sedimentibacter spp. within the Clostridia, as well as Desulfobulbaceae and Geobacter spp., showed a strong association with the lower fringe samples, intermediate toluene concentrations, and high $b s s A$ copy numbers. Desulfobacterium spp. and other Deltaproteobacteria, in addition to diverse Clostridia, were resolved as characteristic for the deeper zone below the plume, showing strong negative correlations with toluene while positive correlations with depth. 

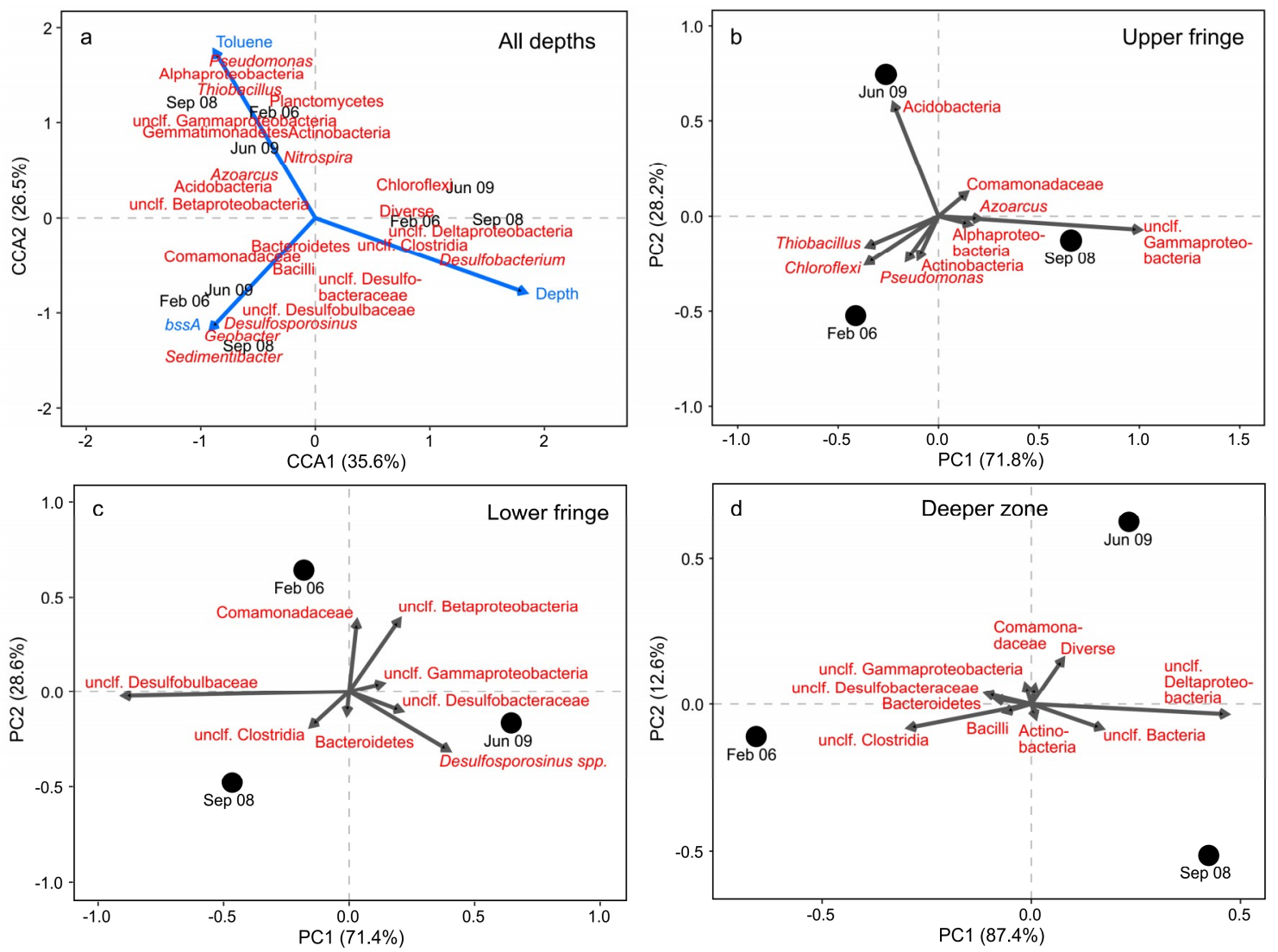

Figure 5. (a) Canonical correspondence analysis (CCA) triplot of overall samples (black), sequencing OTUs (red), and explanatory variables (blue) analyzed in this study. The proportion of inertia explained by the constrained model was $66.1 \%$ of which $62.1 \%$ was retained in the first two axes. Significance of CCA axes and explanatory variables (1000 permutations): CCA1 $(p=0.013)$; CCA2 $(p=0.035)$; toluene concentration $(p=0.009)$, depth below surface $(p=0.008), b s s A$ gene copy numbers $(p=0.025)$. (b-d) PCA biplots showing changes of relative OTU abundances for individual plume zones over the years. All OTUs resolved in sequencing were included in statistical analysis, but for clarity of display, only vectors of OTUs with a combined loading of $>1 \%$ on the first two principle components are shown.

Although the CCA clearly supported distinct niches for OTUs across the plume, the analysis was not sufficient to resolve dynamics in abundances of single taxonomic groups within different zones over the years. Therefore, we analyzed changes in community composition that occurred over time by PCA for each individual plume zone. For the upper fringe (Figure 5b), dynamics in community composition appeared most strongly driven by abundance changes of Gammaproteobacteria other than Pseudomonas spp. in 2008 (contributing 69\% to PC1), and Acidobacteria (contributing 60\% to PC2), which strongly increased in 2009. Community dynamics at the lower fringe (Figure 5c) were mainly associated to changes in abundance of the Desulfobulbaceae (contributing 73\% to PC1) and Desulfosporosinus spp. (contributing $14 \%$ and $21 \%$ to PC1 and PC2, respectively). A sharp negative correlation of Desulfobulbaceae was found to PC1 and especially the 2009 sample. In contrast, Desulfosporosinus spp. exhibited an opposed pattern and a strong negative correlation with the Desulfobulbaceae. In addition, the Comamonadaceae and diverse Betaproteobacteria (contributing 31\% and 32\% to PC2, respectively) had positive correlations to the 2006 sample. Community dynamics in the deeper zone (Figure 5d) appeared mainly driven by a decrease of diverse Clostridia (contributing 23\% to PC1) especially between 2006 and 2008, and a concomitant increase of diverse Deltaproteobacteria (contributing 59\% to PC1). However, in contrast to the plume fringes, species abundances only changed marginally after 
2008: the sample points for 2008 and 2009 were mainly separated by PC2, which only accounted for a small fraction $(12.6 \%)$ of the explained variance.

\section{Discussion}

\subsection{Hydraulic Dynamics and Biodegradation}

This field study demonstrates that hydraulic dynamics of a contaminant plume can be paralleled by dynamics of biogeochemical processes, pollutant degradation, and plume microbiota in situ. It should be cautiously discussed, however, whether the observed biogeochemical dynamics of the plume were essentially linked to the fluctuations of the water table, or possibly also to other driving mechanisms. A number of previous studies have demonstrated that feedbacks between recharge processes, seasonal water table fluctuations, and biodegradation processes actually exist in porous media [17-19,37]. However, it is also well established that seasonal variability of groundwater flow direction can profoundly influence the measurement of contaminants and redox species at defined sampling locations [38,39]. In our case, long-term monitoring data of groundwater flow by the site owner as well as the continued centric localization of the HR-MLW within the lateral plume transect (Figure S1) suggest that variable groundwater flow directions were not a major contributor to biogeochemical variability of vertical plume transects observed over this study.

Thus, an impact of vertical hydraulic fluctuations (Figure 1) on the plume system seemed at least probable. However, even without assuming direct feedbacks on the microbes, water table fluctuations can be expected to impact contaminant loads and redox compartments in plumes [39]. Complex and spatially variable source zones of hydrocarbons exist in the subsurface of many contaminated sites, including in Flingern. Thus, a rise of the groundwater table could have increased the contribution of a secondary hydrocarbon source zone to the plume, which could have caused the increase in maximal toluene concentrations in 2008. The observed leveling-out of toluene $\delta^{13} \mathrm{C}$ isotope ratios at increased ratios in the same year (Figure $2 \mathrm{~b}$ ) was also consistent with the possible intrusion of a secondary contaminant source [40]. Nevertheless, the loss of toluene stable isotope fractionation at the plume fringes in 2008 remains a strong indicator for decreased biodegradation activities [41]. The stimulated sulfidogenesis observed in the same year could either have been connected to oxidation processes other than that of toluene, or to the establishment of a secondary toluene degrader population with a less pronounced isotope fractionation pattern. Consistently, carbon and hydrogen stable isotope studies have reported distinct enrichment factors for a number of anaerobic degraders of BTEX hydrocarbons within the Deltaproteobacteria, Betaproteobacteria, and Clostridia [42,43]. In summary, our biogeochemical data suggests that the pronounced dynamics of contaminant distribution and biodegradation processes observed at the site were, at least in part, attributed to hydraulic dynamics during our study.

\subsection{Dynamics of Plume Microbiota}

At the Flingern site, the importance of the lower plume fringe for anaerobic toluene degradation and a corresponding enrichment of degrader populations within the Desulfobulbaceae have been previously demonstrated [12,13]. Thus, it was not surprising that also in the present study, the lower fringe always carried the highest absolute and relative abundance of $b s s A$ genes (Figure 2), as well as the lowest diversity and highest functional organization of degrader communities (Figure S3). This was in line with the concept of a high specialization of the respective microbial community [44]. DNA-stable isotope probing (SIP) experiments with lower fringe sediments taken in 2008 have previously proven the affiliation of the quantified $b s s A$ genes to the detected Desulfobulbaceae, and verified an important role of this population in toluene degradation under sulfate reduction in situ [27]. Prior to the plume dynamics after 2006, these Desulfobulbaceae continued to dominate the degrader community at the lower fringe. Closely related Desulfobulbaceae have also been identified as sulfidogenic toluene degraders in other contaminated terrestrial subsurface systems [45-47] and seem of considerable 
environmental importance [11]. The most closely related available isolate, Desulfoprunum benzoelyticum, albeit not yet tested for aromatics, has been shown to degrade benzoate [48], a central intermediate of anaerobic aromatics degradation.

After the dynamics of the plume, Desulfosporosinus spp. populations increased in abundance and appeared to replace the previously dominating Desulfobulbaceae at the lower plume fringe. This abundance switching was not only observed in sequencing libraries, but consistently found in biologically replicated T-RFLP fingerprinting (Figure S4) and supported also by multivariate statistics (Figure 5). This demonstrates the utility of combined sequencing and fingerprinting datasets in environmental studies [49]. Members of the genus Desulfosporosinus are also known as sulfate-reducing toluene degraders in terrestrial systems [46,50,51], and have also been found at the Flingern site [27]. At the same time, other members of the lower fringe community remained relatively stable in abundance over time (e.g., the Geobacteraceae), suggesting that community shifts occurred specifically for sulfate-reducing toluene degraders.

The establishment of Desulfosporosinus spp. degraders was not apparent on a catabolic gene level, as bss $A$ ratios remained low in 2009 (Figure 3c). However, the employed qPCR assay specifically targets the Desulfobulbaceae 'F1-cluster' bss A genes originally dominating at the site [12,35]. While more advanced primer sets capable of targeting clostridial $b s s A$ genes are now available [52], the detection of this gene lineage was not conducted in the present study.

It must be cautiously discussed whether the hydraulic and biogeochemical dynamics of the plume could indeed have been connected to the observed switching in abundant degrader populations at the lower fringe. Specific ecological features of the Gram-positives, such as spore formation, could have been involved in an improved resistance to and recovery of these populations after hydraulic forcing. Repeated stress and reactivation cycles are amongst the prime mechanisms proposed to maintain microbial diversity and functional redundancy in natural habitats [53]. However, as our observations come from a complex field setting, a direct coupling between hydraulic and microbial habitat dynamics cannot be unambiguously proven. This clearly calls for a more controlled experimental verification under laboratory conditions. Nevertheless, hydraulically induced plume shifts could represent an under-regarded deterministic factor controlling aquifer microbial community assembly and biogeochemical activities in contaminated systems. Similar feedback mechanisms have also been revealed for hydraulically driven solute and nutrient fluxes at a surface water-groundwater interface $[54,55]$. In unconfined porous aquifers, water table fluctuations are directly connected to dynamic recharge regimes. Since the frequency and intensity of precipitation extremes is predicted to increase in the near future [56], a better understanding of the consequences for aquifer biogeochemistry and groundwater quality may be urgently needed.

\subsection{Conclusions}

In summary, our results provide evidence that complex couplings exist between hydraulic forcing, degrader community dynamics, and contaminant degradation in situ. Functional redundancy amongst anaerobic hydrocarbon degrader populations might have been relevant in sustaining biodegradation after habitat dynamics. Hence, contaminant plumes should be more comprehensively investigated as a habitat of dynamic microbial communities, both in controlled laboratory systems, but also in the field. This is relevant for established monitoring and also management strategies for contaminated sites, where spatially explicit and fine-scale plume transects are still rarely considered [11,57]. We suggest that focusing not only on degrader abundance, but also on degrader diversity and dynamics provides an improved ecological understanding of contaminated groundwater systems, where feedbacks between abiotic and biotic ecosystem components are largely under-regarded.

Supplementary Materials: The following are available online at http:/ /www.mdpi.com/2076-2607/7/2/46/s1: Figure S1. Localization and horizontal extent of the toluene plume at the Flingern site over time; Figure S2. Depth profiles of benzene and naphthalene concentrations on Sep. 2008 and Jun. 2009; Figure S3. Diversity indices of depth-resolved amplicon sequencing libraries of bacterial 16S rRNA gene fragments; Figure S4. Phylogenetic 
affiliation of selected assembled pyrosequencing contigs of $\sim 520$ bp bacterial $16 \mathrm{~S}$ rRNA gene fragments retrieved from different depths of the Flingern aquifer; Figure S5. Depth-distribution of relative T-RF abundance of characteristic degrader populations in replicate T-RFLP fingerprinting per sediment depth and time point.

Author Contributions: G.P. performed field sampling and molecular biology analyses, evaluated NGS data, and wrote parts of the manuscript; A.B. performed sampling, analyzed on-site hydrogeochemistry, and edited the manuscript; B.R.-A. contributed to 2006 hydrogeochemical analyses and edited the manuscript; L.F. performed multivariate statistics and wrote parts of the manuscript; M.E. generated NGS data and edited the manuscript; C.G. designed the study, contributed to hydrogeochemical data evaluation, and wrote parts of the manuscript; T.L. designed the study, contributed to molecular data evaluation, and wrote the manuscript.

Funding: This work was supported by grants from the Deutsche Forschungsgemeinschaft within the Research Unit 'Analysis and Modelling of Diffusion/Dispersion-limited Reactions in Porous Media' (FOR 525) to T.L. and C.G. (LU 1188/2-2 \& GR 2107/1-2). T.L. also acknowledges support of the European Research Council (ERC), grant agreement 616644 (POLLOX) to this research.

Acknowledgments: We thank K. Hörmann for expert technical assistance, M. Elsner and his lab for support in stable isotope analysis (all Helmholtz Zentrum München). Site access in Flingern was provided by L. Richters and the Stadtwerke Düsseldorf (SWD), Germany. The SWD are acknowledged for the data and graphs in Figure S1, with support of BFM-Umwelt (Munich, Germany) for the graph of 2009.

Conflicts of Interest: The authors declare no conflict of interest.

\section{References}

1. Oki, T.; Kanae, S. Global hydrological cycles and world water resources. Science 2006, 313, $1068-1072$. [CrossRef] [PubMed]

2. Griebler, C.; Malard, F.; Lefébure, T. Current developments in groundwater ecology-From biodiversity to ecosystem function and services. Curr. Opin. Biotechnol. 2014, 27, 159-167. [CrossRef] [PubMed]

3. Griebler, C.; Lueders, T. Microbial biodiversity in groundwater ecosystems. Freshw. Biol. 2009, 54, 649-677. [CrossRef]

4. Hancock, P.J.; Boulton, A.J.; Humphreys, W.F. Aquifers and hyporheic zones: Towards an ecological understanding of groundwater. Hydrogeol. J. 2005, 13, 98-111. [CrossRef]

5. Weiss, J.V.; Cozzarelli, I.M. Biodegradation in contaminated aquifers: Incorporating microbial/molecular methods. Ground Water 2008, 46, 305-322. [CrossRef] [PubMed]

6. Hendrickx, B.; Dejonghe, W.; Boenne, W.; Brennerova, M.; Cernik, M.; Lederer, T.; Bucheli-Witschel, M.; Bastiaens, L.; Verstraete, W.; Top, E.M.; et al. Dynamics of an oligotrophic bacterial aquifer community during contact with a groundwater plume contaminated with benzene, toluene, ethylbenzene, and xylenes: An in situ mesocosm study. Appl. Environ. Microbiol. 2005, 71, 3815-3825. [CrossRef]

7. Fahy, A.; Lethbridge, G.; Earle, R.; Ball, A.S.; Timmis, K.N.; McGenity, T.J. Effects of long-term benzene pollution on bacterial diversity and community structure in groundwater. Environ. Microbiol. 2005, 7, 1192-1199. [CrossRef]

8. Yagi, J.M.; Neuhauser, E.F.; Ripp, J.A.; Mauro, D.M.; Madsen, E.L. Subsurface ecosystem resilience: Long-term attenuation of subsurface contaminants supports a dynamic microbial community. ISME J. 2010, 4, 131-143. [CrossRef]

9. Tischer, K.; Kleinsteuber, S.; Schleinitz, K.M.; Fetzer, I.; Spott, O.; Stange, F.; Lohse, U.; Franz, J.; Neumann, F.; Gerling, S.; et al. Microbial communities along biogeochemical gradients in a hydrocarbon-contaminated aquifer. Environ. Microbiol. 2013, 15, 2603-2615. [CrossRef]

10. Fahrenfeld, N.; Cozzarelli, I.; Bailey, Z.; Pruden, A. Insights into biodegradation through depth-resolved microbial community functional and structural profiling of a crude-oil contaminant plume. Microb. Ecol. 2014, 68, 453-462. [CrossRef]

11. Lueders, T. The ecology of anaerobic degraders of BTEX hydrocarbons in aquifers. FEMS Microbiol. Ecol. 2017, 93, fiw220. [CrossRef] [PubMed]

12. Winderl, C.; Anneser, B.; Griebler, C.; Meckenstock, R.U.; Lueders, T. Depth-resolved quantification of anaerobic toluene degraders and aquifer microbial community patterns in distinct redox zones of a tar oil contaminant plume. Appl. Environ. Microbiol. 2008, 74, 792-801. [CrossRef] [PubMed]

13. Anneser, B.; Pilloni, G.; Bayer, A.; Lueders, T.; Griebler, C.; Einsiedl, F.; Richters, L. High resolution analysis of contaminated aquifer sediments and groundwater-What can be learned in terms of natural attenuation? Geomicrobiol. J. 2010, 27, 130-142. [CrossRef] 
14. Einsiedl, F.; Pilloni, G.; Ruth-Anneser, B.; Lueders, T.; Griebler, C. Spatial distributions of sulphur species and sulphate-reducing bacteria provide insights into sulphur redox cycling and biodegradation hot-spots in a hydrocarbon-contaminated aquifer. Geochim. Cosmochim. Acta 2015, 156, 207-221. [CrossRef]

15. Jobelius, C.; Ruth, B.; Griebler, C.; Meckenstock, R.U.; Hollender, J.; Reineke, A.; Frimmel, F.H.; Zwiener, C. Metabolites indicate hot spots of biodegradation and biogeochemical gradients in a high-resolution monitoring well. Environ. Sci. Technol. 2010, 45, 474-481. [CrossRef] [PubMed]

16. Meckenstock, R.U.; Elsner, M.; Griebler, C.; Lueders, T.; Stumpp, C.; Aamand, J.; Agathos, S.N.; Albrechtsen, H.-J.; Bastiaens, L.; Bjerg, P.L.; et al. Biodegradation: Updating the concepts of control for microbial cleanup in contaminated aquifers. Environ. Sci. Technol. 2015, 49, 7073-7081. [CrossRef] [PubMed]

17. Van Stempvoort, D.R.; Armstrong, J.; Mayer, B. Seasonal recharge and replenishment of sulfate associated with biodegradation of a hydrocarbon plume. Groundwater Monit. Remediat. 2007, 27, 110-121. [CrossRef]

18. Scholl, M.A.; Cozzarelli, I.M.; Christenson, S.C. Recharge processes drive sulfate reduction in an alluvial aquifer contaminated with landfill leachate. J. Contam. Hydrol. 2006, 86, 239-261. [CrossRef]

19. Fretwell, B.A.; Burgess, W.G.; Barker, J.A.; Jefferies, N.L. Redistribution of contaminants by a fluctuating water table in a micro-porous, double-porosity aquifer: Field observations and model simulations. J. Contam. Hydrol. 2005, 78, 27-52. [CrossRef]

20. Haack, S.K.; Fogarty, L.R.; West, T.G.; Alm, E.W.; McGuire, J.T.; Long, D.T.; Hyndman, D.W.; Forney, L.J. Spatial and temporal changes in microbial community structure associated with recharge-influenced chemical gradients in a contaminated aquifer. Environ. Microbiol. 2004, 6, 438-448. [CrossRef]

21. Qiu, J. China to spend billions cleaning up groundwater. Science 2011, 334, 745. [CrossRef] [PubMed]

22. Smith, H.J.; Zelaya, A.J.; De León, K.B.; Chakraborty, R.; Elias, D.A.; Hazen, T.C.; Arkin, A.P.; Cunningham, A.B.; Fields, M.W. Impact of hydrologic boundaries on microbial planktonic and biofilm communities in shallow terrestrial subsurface environments. FEMS Microbiol. Ecol. 2018, 94, fiy191. [CrossRef] [PubMed]

23. Wisotzky, F.; Eckert, P. Sulfat-dominierter BTEX-Abbau im Grundwasser eines ehemaligen Gaswerksstandortes. Grundwasser 1997, 2, 11-20. [CrossRef]

24. Anneser, B.; Einsiedl, F.; Meckenstock, R.U.; Richters, L.; Wisotzky, F.; Griebler, C. High-resolution monitoring of biogeochemical gradients in a tar oil-contaminated aquifer. Appl. Geochem. 2008, 23, 1715-1730. [CrossRef]

25. Kuhn, T.K.; Hamonts, K.; Dijk, J.A.; Kalka, H.; Stichler, W.; Springael, D.; Dejonghe, W.; Meckenstock, R.U. Assessment of the intrinsic bioremediation capacity of an eutrophic river sediment polluted by discharging chlorinated aliphatic hydrocarbons: A compound-specific isotope approach. Environ. Sci. Technol. 2009, 43, 5263-5269. [CrossRef] [PubMed]

26. Sherwood Lollar, B.; Hirschorn, S.K.; Chartrand, M.M.G.; Lacrampe-Couloume, G. An approach for assessing total instrumental uncertainty in compound-specific carbon isotope analysis: Implications for environmental remediation studies. Anal. Chem. 2007, 79, 3469-3475. [CrossRef] [PubMed]

27. Pilloni, G.; von Netzer, F.; Engel, M.; Lueders, T. Electron acceptor-dependent identification of key anaerobic toluene degraders at a tar-oil-contaminated aquifer by Pyro-SIP. FEMS Microbiol. Ecol. 2011, 78, 165-175. [CrossRef] [PubMed]

28. Pilloni, G.; Granitsiotis, M.S.; Engel, M.; Lueders, T. Testing the limits of 454 pyrotag sequencing: Reproducibility, quantitative assessment and comparison to T-RFLP fingerprinting of aquifer microbes. PLOS ONE 2012, 7, e40467. [CrossRef]

29. Karwautz, C.; Lueders, T. Impact of hydraulic well restoration on native bacterial communities in drinking water wells. Microbes Environ. 2014, 29, 363-369. [CrossRef]

30. Schloss, P.D. A high-throughput DNA sequence aligner for microbial ecology studies. PLoS ONE 2009, 4, e8230. [CrossRef]

31. Quast, C.; Pruesse, E.; Yilmaz, P.; Gerken, J.; Schweer, T.; Yarza, P.; Peplies, J.; Glöckner, F.O. The SILVA ribosomal RNA gene database project: Improved data processing and web-based tools. Nucleic Acids Res. 2013, 41, D590-D596. [CrossRef] [PubMed]

32. Marzorati, M.; Wittebolle, L.; Boon, N.; Daffonchio, D.; Verstraete, W. How to get more out of molecular fingerprints: Practical tools for microbial ecology. Environ. Microbiol. 2008, 10, 1571-1581. [CrossRef] [PubMed]

33. Ter Braak, C.J.F.; Verdonschot, P.F.M. Canonical correspondence analysis and related multivariate methods in aquatic ecology. Aquat. Sci. 1995, 57, 255-289. [CrossRef] 
34. Oksanen, J.; Blanchet, F.G.; Friendly, M.; Kindt, R.; Legendre, P.; McGlinn, D.; Minchin, P.R.; O’Hara, R.B.; Simpson, G.L.; Solymos, P.; et al. Vegan: Community Ecology Package. Ordination Methods, Diversity Analysis and Other Functions for Community and Vegetation Ecologists. R Package Version: 2.4-2. Available online: https: / / cran.r-project.org/web/packages/vegan (accessed on 9 February 2019).

35. Von Netzer, F.; Kuntze, K.; Vogt, C.; Richnow, H.H.; Boll, M.; Lueders, T. Functional gene markers for fumarate-adding and dearomatizing key enzymes in anaerobic aromatic hydrocarbon degradation in terrestrial environments. J. Mol. Microbiol. Biotechnol. 2016, 26, 180-194. [CrossRef] [PubMed]

36. Larentis, M.; Hoermann, K.; Lueders, T. Fine-scale degrader community profiling over an aerobic/anaerobic redox gradient in a toluene-contaminated aquifer. Environ. Microbiol. Rep. 2013, 5, 225-234. [CrossRef] [PubMed]

37. Rezanezhad, F.; Couture, R.M.; Kovac, R.; O'Connell, D.; Van Cappellen, P. Water table fluctuations and soil biogeochemistry: An experimental approach using an automated soil column system. J. Hydrol. 2014, 509, 245-256. [CrossRef]

38. Rein, A.; Bauer, S.; Dietrich, P.; Beyer, C. Influence of temporally variable groundwater flow conditions on point measurements and contaminant mass flux estimations. J. Contam. Hydrol. 2009, 108, 118-133. [CrossRef] [PubMed]

39. Wilson, R.D.; Thornton, S.F.; Mackay, D.M. Challenges in monitoring the natural attenuation of spatially variable plumes. Biodegradation 2004, 15, 359-369. [CrossRef]

40. Jeffrey, A.W. Application of stable isotope ratios in spilled oil identification. In Oil Spill Environmental Forensics: Fingerprinting and Source Identification; Wang, Z., Stout, S., Eds.; Academic Press: New York, NY, USA, 2007; pp. 207-227.

41. Elsner, M. Stable isotope fractionation to investigate natural transformation mechanisms of organic contaminants: Principles, prospects and limitations. J. Environ. Monit. 2010, 12, 2005-2031. [CrossRef]

42. Kümmel, S.; Kuntze, K.; Vogt, C.; Boll, M.; Heider, J.; Richnow, H.H. Evidence for benzylsuccinate synthase subtypes obtained by using stable isotope tools. J. Bacteriol. 2013, 195, 4660-4667. [CrossRef]

43. Herrmann, S.; Vogt, C.; Fischer, A.; Kuppardt, A.; Richnow, H.-H. Characterization of anaerobic xylene biodegradation by two-dimensional isotope fractionation analysis. Environ. Microbiol. Rep. 2009, 1, 535-544. [CrossRef] [PubMed]

44. Read, S.; Marzorati, M.; Guimarães, B.M.; Boon, N. Microbial Resource Management revisited: Successful parameters and new concepts. Appl. Microbiol. Biotechnol. 2011, 90, 861-871. [CrossRef] [PubMed]

45. Bombach, P.; Chatzinotas, A.; Neu, T.R.; Kästner, M.; Lueders, T.; Vogt, C. Enrichment and characterization of a sulfate-reducing toluene-degrading microbial consortium by combining in situ microcosms and stable isotope probing techniques. FEMS Microbiol. Ecol. 2010, 71, 237-246. [CrossRef] [PubMed]

46. Sun, W.; Cupples, A.M. Diversity of five anaerobic toluene-degrading microbial communities investigated using stable isotope probing. Appl. Environ. Microbiol. 2012, 78, 972-980. [CrossRef] [PubMed]

47. Abu Laban, N.; Dao, A.; Foght, J. DNA stable-isotope probing of oil sands tailings pond enrichment cultures reveals different key players for toluene degradation under methanogenic and sulfidogenic conditions. FEMS Microbiol. Ecol. 2015, 91, fiv039. [CrossRef]

48. Junghare, M.; Schink, B. Desulfoprunum benzoelyticum gen. nov., sp. nov., a Gram-stain-negative, benzoate-degrading, sulfate-reducing bacterium isolated from a wastewater treatment plant. Int. J. Syst. Evol. Microbiol. 2015, 65, 77-84. [CrossRef] [PubMed]

49. Van Dorst, J.; Bissett, A.; Palmer, A.S.; Brown, M.; Snape, I.; Stark, J.S.; Raymond, B.; McKinlay, J.; Ji, M.; Winsley, T.; et al. Community fingerprinting in a sequencing world. FEMS Microbiol. Ecol. 2014, 89, 316-330. [CrossRef]

50. Winderl, C.; Penning, H.; von Netzer, F.; Meckenstock, R.U.; Lueders, T. DNA-SIP identifies sulfate-reducing Clostridia as important toluene degraders in tar-oil-contaminated aquifer sediment. ISME J. 2010, 4, 1314-1325. [CrossRef]

51. Liu, A.; Garcia-Dominguez, E.; Rhine, E.D.; Young, L.Y. A novel arsenate respiring isolate that can utilize aromatic substrates. FEMS Microbiol. Ecol. 2004, 48, 323-332. [CrossRef]

52. Von Netzer, F.; Pilloni, G.; Kleindienst, S.; Krüger, M.; Knittel, K.; Gründger, F.; Lueders, T. Enhanced gene detection assays for fumarate-adding enzymes allow uncovering anaerobic hydrocarbon degraders in terrestrial and marine systems. Appl. Environ. Microbiol. 2013, 79, 543-552. [CrossRef] 
53. Jones, S.E.; Lennon, J.T. Dormancy contributes to the maintenance of microbial diversity. Proc. Natl. Acad. Sci. USA 2010, 107, 5881-5886. [CrossRef] [PubMed]

54. Stegen, J.C.; Lin, X.; Konopka, A.E.; Fredrickson, J.K. Stochastic and deterministic assembly processes in subsurface microbial communities. ISME J. 2012, 6, 1653-1664. [CrossRef] [PubMed]

55. Stegen, J.C.; Lin, X.; Fredrickson, J.K.; Chen, X.; Kennedy, D.W.; Murray, C.J.; Rockhold, M.L.; Konopka, A. Quantifying community assembly processes and identifying features that impose them. ISME J. 2013, 7, 2069-2079. [CrossRef] [PubMed]

56. Min, S.-K.; Zhang, X.; Zwiers, F.W.; Hegerl, G.C. Human contribution to more-intense precipitation extremes. Nature 2011, 470, 378-381. [CrossRef] [PubMed]

57. Hazen, T.C. In situ: Groundwater bioremediation. In Consequences of Microbial Interactions with Hydrocarbons, Oils, and Lipids: Biodegradation and Bioremediation; Steffan, R., Ed.; Springer International Publishing: Cham, Switzerland, 2018; pp. 1-18.

(C) 2019 by the authors. Licensee MDPI, Basel, Switzerland. This article is an open access article distributed under the terms and conditions of the Creative Commons Attribution (CC BY) license (http://creativecommons.org/licenses/by/4.0/). 